\title{
A Review of Minimally Invasive Gynecologic Surgery in Developing Nations
}

\author{
Corrie Miller ${ }^{1}$, Karina Hoan ${ }^{2}$, Lucas Minig ${ }^{3}$, Linus Chuang** and Shohreh Shahabi ${ }^{5}$ \\ ${ }^{1}$ Western Connecticut Health Network, USA \\ ${ }^{2}$ Icahn School of Medicine at Mount Sinai New York, USA \\ ${ }^{3}$ Fundación Instituto Valenciano De Oncología, Spain \\ ${ }^{4}$ Icahn School of Medicine at Mount Sinai New York, USA \\ ${ }^{5}$ Feinberg School of Medicine, Northwestern University Chicago IL, USA \\ Submission: March 09, 2017; Published: May 05, 2017 \\ *Corresponding author: Linus Chuang, Department of Obstetrics \& Gynecology and Reproductive Science, Icahn School of Medicine, Mount Sinai, \\ 1176 Fifth Ave, New York NY 10029, USA, Email: linus.chuang@mssm.edu
}

\section{Abstract}

Background and objectives: Endoscopic surgery may have added benefits in low-resource countries including improved recovery time, lower post-operative infection rates and decreased blood loss. These techniques are being used by gynecologists worldwide, but the extent is largely unknown. The aim of this review is to evaluate the laparoscopic gynecologic surgical capacity in low-resource countries and identify economic indicators that are associated with advanced skill.

Methods: An online literature search was conducted; search terms included gynecologic, laparoscopy, minimally invasive, and low-resource countries. Of 336 abstracts identified, 100 articles were chosen in English and Spanish during between 1998-2015. Types of procedures, indications, and complication rates were grouped and compared according to World Bank Income Groups of Developing Nations: Low Income Country (LIC), Low-Middle Income Country (LMIC), or Upper-Middle Income Country (UMIC). Each country was categorized into Categories of complexity based on the highest level of skill required for reported procedures. The level of complexity was compared to World Bank Healthcare Development Indicators to identify correlates of advanced laparoscopic capacity.

Results: $14 \%$ of LIC report performing MIG procedures; twice as many LMIC and UMIC countries report such proficiency. LICs primarily perform diagnostic laparoscopies or adnexal surgery, with infertility being the most common indication. UMICs perform a variety of laparoscopic surgeries for benign and oncologic indications.

Conclusions: Minimally invasive surgery is widely adopted around the world. Advanced laparoscopic surgical procedures are increasingly performed in upper middle-income countries.

Keywords: Minimally invasive gynecologic Surgery; Low-resource settings

\section{Introduction}

There is growing momentum to increase access to surgical services in low-resource countries in order to reduce the global disease burden [1]. The benefits of investing in surgical infrastructure as a public health intervention are now evident. Compared with antiretroviral treatment or vaccinations, surgery can be equally as cost effective in averting Disability Adjusted Life Years (DALYs) and has a strong impact on improving the productivity of a community [2].

As effort is put forth to increase surgical capacity globally, there must be a congruent aim towards safety and quality [3]. Minimally invasive surgery offers benefits such as reduced perioperative complications and improved recovery times that can be all the more beneficial to patients in low resource settings
[4]. General surgery literature has identified many important benefits of minimally invasive techniques in low and middleincome countries. These included decreased infection rates post operatively in environments with suboptimal sanitation and reduced blood loss in the setting of limited blood-banking services [5].

Compared to the United States, thorough record keeping and reliable databases do not exist in most developing countries, leaving a paucity of comprehensive data regarding the promulgation of information about MIGS worldwide. Organizations such as American Association of Gynecologic Laparoscopists (AAGL) and the International Society of Gynecologic Endoscopy (ISGE) are helping to disseminate 
information and research regarding MIGS, but the current capacity of gynecologists to perform laparoscopy worldwide is largely unknown.

The objective of this review is to evaluate the overall capacity of Low and Middle Income Countries (LMICs) in performing MIGS procedures, by comparing procedure type, indication, and complications. Further, we aim to identify economic development indicators within health systems that may be associated with advanced laparoscopic capacity.

\section{Materials and Methods}

An online literature search was performed independently by the two first authors and also a team of two medical librarians using Google Scholar, African Journals Online and Pubmed using the MESH terms: gynecologic, laparoscopy or laparoscopic, minimally invasive, together with the individual names of all developing countries as classified under the World Bank Economic Classification system (Gross National Income (GNI) per Capita of less than $\$ 12,745$ during fiscal year 2013). For instance, the following PUBMED search was performed for each developing nation: ( (C(Laparoscopy"[Mesh] OR "Hand-Assisted Laparoscopy"[Mesh]OR laparoscop*)) AND “Gynecology"[Mesh] OR gynecolog*)) AND ("Egypt"[Mesh]OR Egypt AND Journal Article [ptyp] AND Humans[Mesh] AND English [lang]) Filters: Journal Article, From 1990/01/01 to 2015/12/31, Humans, English, Core clinical journals.

Titles and abstracts were reviewed for articles describing a review of the development or current state of gynecologic surgery. As there is no universally agreed upon definition of Minimally Table 1: Complexity Categories.

\begin{tabular}{|c|c|c|}
\hline Procedures & Complexity Category & Countries Assigned \\
\hline Training Camps & \multirow{4}{*}{ Diagnostic Procedures } & \multirow{4}{*}{$\begin{array}{c}\text { Albania, Cameroon, Haiti, Hungary, Mexico, Romania, Rwanda, } \\
\text { Tajikistan }\end{array}$} \\
\hline Diagnostic Laparoscopy & & \\
\hline Chromotubation & & \\
\hline Hysteroscopy & & \\
\hline Bilateral Tubal Ligation & \multirow{9}{*}{ Operative Procedures } & \multirow{9}{*}{$\begin{array}{l}\text { Bangladesh, China, Cuba, Ecuador, Egypt, Ghana, Honduras, } \\
\text { Iran, Kenya, Lebanon, Malaysia, Nepal, Nigeria, Pakistan, } \\
\text { Paraguay, Peru, Serbia, South Africa, Sri Lanka, Sudan, Thailand, } \\
\text { Uzbekistan, Vietnam }\end{array}$} \\
\hline Ovarian Drilling & & \\
\hline Tuboplasty & & \\
\hline Salpingectomy (Ectopic) & & \\
\hline Adnexal Surgery & & \\
\hline Myomectomy & & \\
\hline $\begin{array}{l}\text { Laparoscopic Assisted Vaginal } \\
\text { Hysterectomy }\end{array}$ & & \\
\hline Total Laparoscopic Hysterectomy & & \\
\hline Urogynecologic/Pelvic Floor Procedures & & \\
\hline Sacrocolpopexy & \multirow{5}{*}{$\begin{array}{l}\text { Procedures requiring advanced } \\
\text { sub-specialty training }\end{array}$} & \multirow{5}{*}{ Argentina, Brazil, Colombia, India, Turkey, Ukraine, Venezuela } \\
\hline $\begin{array}{l}\text { Robotic Assisted Total Laparoscopic } \\
\text { Hysterectomy }\end{array}$ & & \\
\hline $\begin{array}{l}\text { Robotic Assisted Repair of Vesico-vaginal } \\
\text { fistula }\end{array}$ & & \\
\hline Radical Hysterectomy/Staging & & \\
\hline Exeneration & & \\
\hline
\end{tabular}

Invasive Gynecologic Surgery, we included hysteroscopy, laparoscopy, robotic surgery, and pelvic floor procedures when referring to MIGS. Abstracts published between 1990 and 2015in English or Spanish were reviewed. Citations of retrieved articles were searched to identify additional relevant articles.

\section{Study selection}

Observational prospective studies, retrospective series, and case reports were included in the review. Articles describing a single indication for minimally invasive surgery or case series with laparoscopic treatment were also included. Literature reviews and editorials published by LMICs were excluded. In order to further characterize capacity and complexity of laparoscopic surgery in developing nations, abstracts presented at international conferences were included in the review if they included data about surgical capacity.

When applicable, the following information was extracted from each article: the overall incidence of gynecologic procedures performed via MIG techniques in the respective country, the types of procedures performed, the most common indications for surgery and complications encountered.

Data was grouped according to the Gross National Income (GNI) per Capita, and thus World Bank categorization of Low Income Country (LIC), Low-Middle Income Country (LMIC), or Upper-Middle Income Country (UMIC). The World Bank groups developing nations into the following three categories based on income: LICs have a GNI per capita (Fiscal Year 2013) of $\$ 1,045$ or less; LMICs, $\$ 1,046-\$ 4,125$; UMICs, $\$ 4,126$ to $\$ 12,745$. 
The complexity of various types of surgical procedures was ranked into three categories (Table 1): Diagnostic, Operative or Advanced Subspecialty training. Countries were assigned a Complexity Category based on the most difficult procedure reported in their literature. Countries only reporting basic diagnostic procedures with minimal operative performance such as hysteroscopy or diagnostic laparoscopy performed were assigned to the Diagnostic Category. Those publishing outcomes of operative procedures such as salpingo-oophorectomy or hysterectomy were placed in the Operative Category. Finally, countries demonstrating ability to execute procedures that require more technological skill and subspecialty training, such as a laparoscopic radical hysterectomy or lymphadenectomy, were assigned to the Advanced Category. These three categories were used to classify the types of procedures performed in LIC and LMIC as well as identify economic determinants that may confer advanced skill.

The three Complexity Categories were compared with economic income group and compared using a one-way ANOVA test. They were also compared against World Bank Healthcare Development indicators. These included: Total healthcare expenditure as a percent of GDP, healthcare expenditure per capita (in USD), percentage of public, out-of-pocket, and external resource health care expenditure, population, Income GINI Coefficient, hospital beds per 1000 people, and physicians per 1,000 people. By looking at these parameters, we aimed to identify factors that contributed to advanced laparoscopic skill. A one-tailed ANOVA test was used to compare the averages within each Complexity Category of each development indicator and identify a trend toward advanced surgical skill. Economic measures were obtained from the World Bank Database, with the most recent indicator from the last 10 years was used.

\section{Results}

One-hundred articles fit the inclusion criteria, taking place in 38 different countries. Table 2 shows the number of articles obtained for each country.

Table 2: Articles Included in Review according to Country; Supplementary Material: Full Bibliography.

\begin{tabular}{|c|c|c|}
\hline Country & Number of Articles & Citation \\
\hline Albania & 1 & Habibaj [1] \\
\hline Argentina & 4 & Sardi [2], Vidaurreta [3], Buquesta[4], Kreiker [5] \\
\hline Bangledesh & 2 & Jahan [6], Jahan [7] \\
\hline Brazil & 2 & Djedian [8]; Gomes [9] \\
\hline Cameroon & 2 & Mboudou [10]; Raiga [11] \\
\hline China & 3 & Yi [12]; Lin [13]; Wang [14] \\
\hline Colombia & 1 & Pareja [15] \\
\hline Cuba & 1 & Gonzalez [16] \\
\hline Ecuador & 1 & Krentel [17] \\
\hline Egypt & 5 & Siam [18]; Saman [19], Siam [20]; Abuelghar [21], Mohamed [22] \\
\hline Ghana & 2 & Andreatta [23]; Kim [24] \\
\hline Haiti & 1 & Maxis [25] \\
\hline Honduras & 1 & Roberto 2014 \\
\hline Hungary & 3 & Szendi [26]; Torok [27]; Drozgyik [28] \\
\hline India & 9 & Puntambekar [29-31]; Hemal [32], Puri [33], Shrivastava [34], Wadia [35] \\
\hline Iran & 4 & Abdollahi [36], Alborzi [37-39] \\
\hline Kenya & 5 & Parkar [40-42], Sikolia [43] \\
\hline Lebanon & 1 & Abu-Musa [44] \\
\hline Malaysia & 1 & $\operatorname{Lim}[45]$ \\
\hline Mexico & 2 & Díaz [46], Arellano-Borja [2009] \\
\hline
\end{tabular}




\section{Journal of Gynecology and Women's Health}

\begin{tabular}{|c|c|c|}
\hline Nepal & 3 & Saha $[47,48]$, Shrestha [49] \\
\hline Nigeria & 7 & Efetie [50], Ikechebelu [51], Badejoko [52,53 ], Okunlola [54], Arowojolu [55], Yakasai 2012 \\
\hline Pakistan & 9 & Rehman [56], Rizci [57,58], Mushtaq [59], Parveen [60,61], Memon [62,63], Iftikhar [64] \\
\hline Paraguay & 2 & Molinas [65]; Ferreira [66] \\
\hline Peru & 2 & Rechkemmer [67]; Rechkemmer [68] \\
\hline Romania & 1 & Dragusin [69] \\
\hline Rwanda & 2 & Dhont [70];Faisal Hospital 2012 \\
\hline Serbia & 2 & Popović [71];Prorocic [72] \\
\hline South Africa & 1 & Butt [73] \\
\hline Sri Lanka & 2 & Rajayana [2014], Gunawardena [74] \\
\hline Sudan & 2 & Mirghani [75]; Omer [76] \\
\hline Tajikistan & 1 & Kassam [77] \\
\hline Thailand & 6 & $\begin{array}{c}\text { Manchana [78]; Wongpia [79]; Nutthachote [80]; Teerapong [81]; Khampitak [82], } \\
\text { Tanaprasertkul [83] }\end{array}$ \\
\hline Turkey & 3 & Nazik [84]; Capar [85], Gocmen [86] \\
\hline Ukraine & 1 & Baydo [87] \\
\hline Uzbekistan & 2 & Narzullaev [88]; Kalegyn [89] \\
\hline Venezuela & 2 & Sotelo $[90,91]$ \\
\hline Vietnam & 1 & Nguyen [92] \\
\hline
\end{tabular}

The rate of countries reporting laparoscopic capabilities increased proportionately according to each income group with only 6 out of $34(14.71 \%)$ LICs reporting experience with MIG procedures, while 19 of 55 (34.55\%) UMICs described their experience in the literature (Figure 1). The incidence of
MIGS procedures in relation to all gynecologic procedures was reported to be between $2.9-12 \%$ in the majority of LIC countries [6-8]. One outlying article from Nigeria stated that $23.7 \%$ of all gynecologic surgery was performed via laparoscopy [9].

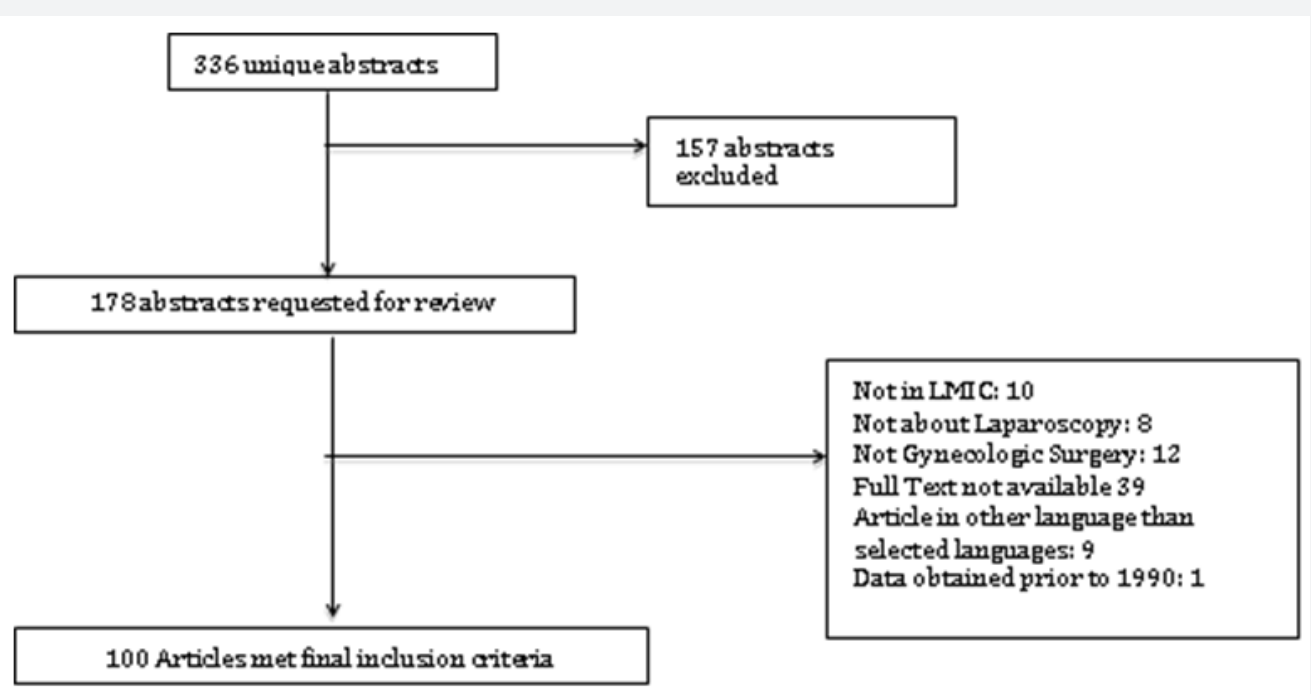

Figure 1: Selection of Included Articles. 
Table 3: Number of Publications according to Primary Indication for MIGS within each Economic Income Group.

\begin{tabular}{|c|c|c|c|}
\hline Indication for Surgery & LIC $\mathbf{n = 1 4}$ & LMIC $\mathbf{n}=\mathbf{4 6}$ & UMIC $\mathbf{n = 4 0}$ \\
\hline Infertility & 3 & 22 & 7 \\
\hline Teaching Camp & 3 & 3 & 1 \\
\hline Ectopic & 1 & 5 & 2 \\
\hline $\begin{array}{c}\text { Pelvic Pain/ } \\
\text { dysmenorrhea }\end{array}$ & 1 & 3 & 3 \\
\hline Malignancy & 1 & 4 & 4 \\
\hline Uterine Perforation & 1 & 0 & 0 \\
\hline AUB or Leiomyoma & 2 & 0 & 12 \\
\hline Pelvic Organ Prolapse & 0 & 3 & 2 \\
\hline $\begin{array}{c}\text { SUI } \\
\text { Ovarian Cyst/Mass }\end{array}$ & 0 & 1 & 2 \\
\hline $\begin{array}{c}\text { Vesico-Vaginal Fistula } \\
\text { (or ureteral-vaginal } \\
\text { fistula) }\end{array}$ & 0 & 1 & 4 \\
\hline $\begin{array}{c}\text { Sterilization } \\
\text { Amenorrhea }\end{array}$ & 0 & 1 & 0 \\
\hline
\end{tabular}

The indication most often cited for MIGS procedures in LIC and LMIC countries was a diagnostic evaluation of infertility (Table 3). Of all hysteroscopic and laparoscopic procedures performed in these two economic groups, $70.1 \%$ to $98.4 \%$ of procedures are done in attempt to diagnose fertility issues $[6,7,9]$. In contrast, articles from UMIC report a wider range of indications for MIGS, varying from treatment of pelvic floor disorders [10] to extensive surgical debulking for gynecological malignancies $[11,12]$.

The Diagnostic, Operative, and Advanced procedures varied between LIC, LMIC and UMIC. LIC only reported procedures in the Diagnostic or Operative Category, while UMIC had more varied distribution of countries reporting procedures in all three categories (Figure 2).

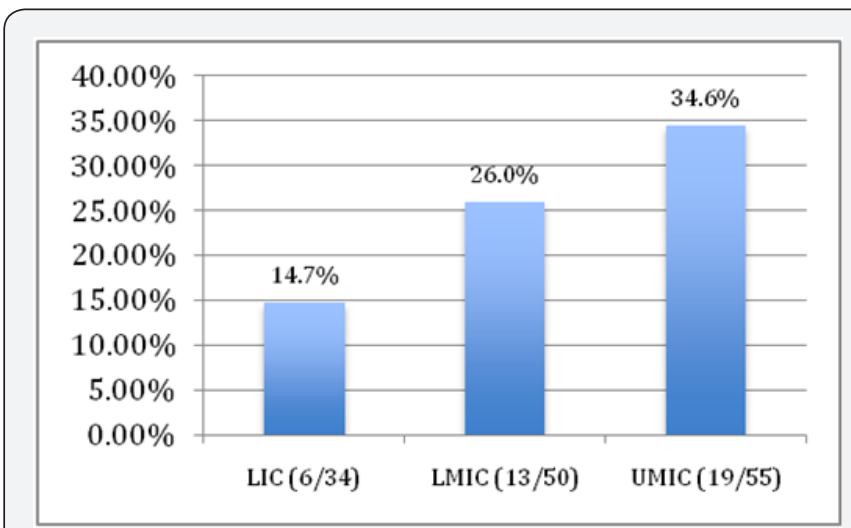

Figure 2: Number of Countries citing ability to perform minimally invasive procedures.

A total of 35 of the 100 articles reported adverse events that occurred during MIGS. The major and minor complication rates, as well as conversion rate to laparotomy, are shown in (Table 4). Major complications include bowel or bladder injury, vessel injury with subsequent hemorrhage, and vesicovaginal fistula. Minor complications include wound infection, separation or hematoma, as well as urinary tract infection, uterine perforation, post-operative lymphocele, vaginal cuff abscess, and ileus. Major complication rates are noted to be highest in UMIC. Yet, conversion rates from a minimally invasive procedure to laparotomy occurred less frequently in UMIC: $1.77 \%$ vs $7.17 \%$ of cases in LIC.

Table 4: Aggregate complication rates cited among economic income groups.

\begin{tabular}{|c|c|c|c|}
\hline & LIC & LMIC & UMIC \\
\hline Major Complications & $0.52 \%$ & $1.27 \%$ & $2.24 \%$ \\
\hline Minor Complications & $5.21 \%$ & $7.48 \%$ & $3.64 \%$ \\
\hline $\begin{array}{c}\text { Conversion to Open } \\
\text { Procedure }\end{array}$ & $7.17 \%$ & $1.43 \%$ & $1.77 \%$ \\
\hline
\end{tabular}

Table 5: Average Economic Determinants among each Complexity Category.

\begin{tabular}{|c|c|c|c|c|c|c|c|c|c|c|}
\hline & $\begin{array}{c}\text { GNI Per } \\
\text { Capita } \\
\text { Atlas } \\
\text { Metho- } \\
\text { dology } \\
2013 \\
\text { (Current } \\
\text { Inter- } \\
\text { national } \\
\text { \$) }\end{array}$ & $\begin{array}{c}\text { Health } \\
\text { Ex- } \\
\text { penditure } \\
\text { Per } \\
\text { Capita } \\
\text { (Current } \\
\text { US\$) }\end{array}$ & $\begin{array}{c}\text { Health } \\
\text { Ex- } \\
\text { penditure } \\
\text { Public } \\
\text { (\% Of } \\
\text { Total } \\
\text { Health } \\
\text { Ex- } \\
\text { penditure) }\end{array}$ & $\begin{array}{l}\text { Health } \\
\text { Ex- } \\
\text { penditure } \\
\text { Total (\% } \\
\text { GDP) }\end{array}$ & $\begin{array}{c}\text { External } \\
\text { Health } \\
\text { Care } \\
\text { Re- } \\
\text { sources }\end{array}$ & $\begin{array}{c}\text { Population, } \\
\text { Total }\end{array}$ & $\begin{array}{l}\text { Out-Of- } \\
\text { Health } \\
\text { Ex- } \\
\text { penditure } \\
\text { (\% Of } \\
\text { Private } \\
\text { Ex- } \\
\text { penditure } \\
\text { on } \\
\text { Health) }\end{array}$ & $\begin{array}{l}\text { GNI Index } \\
\text { (World } \\
\text { Bank- } \\
\text { estimate) }\end{array}$ & $\begin{array}{c}\text { Hospital- } \\
\text { beds } \\
\text { (Per } \\
1,000 \\
\text { People) }\end{array}$ & $\begin{array}{c}\text { Phyisi- } \\
\text { cian } \\
\text { (Per 1,00 } \\
\text { People) }\end{array}$ \\
\hline Diagnostic & 5086.25 & 310.61 & 48.01 & 6.63 & 13.70 & $25,940,327.88$ & 73.08 & 39.02 & 3.39 & 1.36 \\
\hline Operative & 4433.91 & 262.90 & 47.59 & 6.17 & 4.84 & $110,404,757.22$ & 83.03 & 41.17 & 2.19 & 1.35 \\
\hline Advanced & 8055.00 & 599.07 & 55.27 & 6.74 & 0.37 & $241,870,945.71$ & 74.90 & 42.64 & 3.09 & 2.07 \\
\hline
\end{tabular}


The World Bank Healthcare Development Indicators were trended in each Complexity Category (Table 5). Sixty percent $(23 / 38)$ of all countries were assigned to the Operative category. Five of the seven countries categorized in the Advanced Category were UMICs. Two healthcare development indicators demonstrated a trend with Complexity Categorization but did not reach statistical significance. The percentage of healthcare resources originating from outside the country, or "External Healthcare Resources," decreased from countries in the Diagnostic to countries in the Advanced category. $(p=0.055)$. The percentage of healthcare expenditures originating from of external resources was the highest for countries in the diagnostic category at $13.7 \%$, while only $0.37 \%$ of health expenditures were from external resources in the Advanced category.

A trend was noted toward larger populations in the advanced category. The average population of countries in the Diagnostic group was 25 million, 110 million for the operative category, and 241 million in the advanced category. This difference was not statistically significant $(\mathrm{p}=0.35)$. GNI Per Capita, Total Health Expenditure per capita, Public Health Expenditure, Outof-pocket Health expenditures, Total Health Expenditure as a percentage of GDP, Income GINI coefficient, or hospital and physicians per capita did not proportionately increase with Complexity Category.

\section{Discussion}

There is growing consensus that surgical capacity building must become a priority of global health interventions $[13,14]$. Investing in basic surgical services and essential surgical care will be the next large focus of improving healthcare systems in low-resource settings [15]. As this is accomplished, infrastructure will be enhanced and so will the desire to perform minimally invasive procedures, as the benefits of such operations are clear. The advantages of MIGS are well published in UMIC. The same benefits: less wound infection, shorter hospital stay, and decreased blood loss have been demonstrated in various developing countries [16-18].

Our analysis demonstrates that endoscopic surgery can be performed across the globe, but the degree to which these operations are performed varies among income groups. The aim of this study was to identify associations and possible determinants of advanced laparoscopic capacity. The results were consistent with our hypothesis that increased economic development is associated with higher utilization and advanced MIGS skill.

The articles reviewed show that incidence of MIGS performance increases with economic income group. Only 14\% of LIC perform MIG procedures; LMIC and UMIC groups have twice as many countries reporting such proficiency. Higher economic status allows for the acquisition and maintenance of endoscopic equipment, which is a commonly cited barrier to uptake of laparoscopy in developing nations [5]. Fewer LICs and LMICs are able to overcome obstacles in raising capital for the initial purchase of equipment, and often do so by charging much higher prices for laparoscopy over open procedures [19]. A solution to this barrier is to develop a sustainable and continued relationship with an institution in a high-resource nation that is capable of providing training and equipment $[20,21]$.

Indications for MIGS vary between economic groups as well. While LIC and LMIC report infertility and pelvic pain as the most common indications, there is a wider distribution of indications in UMIC. Applying MIGS to more complicated indications requires advanced equipment and training. The percentage of articles citing infertility as the primary indication for MIGS procedures may illuminate the uneven distribution of accessibility and difficulty to integrate the techniques into surgical systems at large. Diagnostic work-up of infertility in LIC and LMICs is often attainable only for patients with more resources to pay for elective procedures [22], thus highlighting a problem with accessibility to minimally invasive techniques. While MIGS procedures are available in low-resource settings, the indications to which they are applied often remain for patients who can afford the higher price of elective operations.

In comparing all reported complication rates of the reviewed literature to economic income group, major complication rates were greater in UMIC compared to LIC. This may be attributed to the types of surgeries performed in each group. While LIC and LMICs mostly describe basic diagnostic and operative laparoscopies, UMIC report complications associated with more technically advanced procedures [23]. All rates are comparable to complications published in high-income countries [24]. With time, the cultivation of laparoscopic skill will decrease complication rates $[24,25]$.

The Development indicators did not reach significance in identifying trends among the three Complexity Categories. While External Healthcare resources had a non-significant trend with Complexity Category, this is likely related to a few outliers who receive a large proportion of their healthcare budget from outside donors. Complexity Category also trended with a country's total population. This relationship may possibly be due to the larger economies of scale in these countries. Greater purchasing power allows hospitals to have capital to invest in the cutting-edge technology such as the Da Vinci System $[23,26]$. The large markets of the "BRICS" Block (Brazil, Russia, India, China and South Africa) also have a larger pool of patients to seek out such procedures and make the initial investment more profitable.

This study is limited by several factors, the largest being publication bias. The amount and quality of data by country is highly variable, as no standardized reporting system exists in most nations globally with regards to MIGS. Many gynecologists in developing nations have adequate resources and training and offer MIGS to their patients but have not published their data. The literature search is also limited by the exclusion of articles 
in languages other than English and Spanish. As discussed, the review also does not talk about the distribution of laparoscopic surgery. A few countries have multiple studies from one author. This likely indicates that there are a limited amount of providers or institutions providing such services, and thus is not reflective of accessibility at large. The small number of countries in this study limited statistical analysis of development indicators and surgical capacity. Greater differences may have been realized with more power $[27,28]$.

Nonetheless, to our knowledge, this is the first comprehensive literature review of gynecologic minimally invasive surgery in developing nations. In the absence of reliable database used globally, it provides a basic scope of the current abilities of gynecologists in low and middle-income countries to offer patients minimal access surgery. The study most importantly shows that laparoscopic surgery can be utilized in low-income countries and that GNI per capita is not necessarily predictive of MIGs capacity. Further research is needed to identify ways of improving capacity in LIC and LMICs. Collaborative relationships with developed nations may play a role, whether through incountry training camps or opportunities abroad. Several articles report that the local surgeons who are performing laparoscopy received their training from physicians in high resource nations $[20,21]$.

Moving forward, well-structured laparoscopic training programs for OB/GYN physicians in low-resource areas will be critical for expanding minimally invasive techniques into these parts of the world and improving patient outcomes [29,30]. The information obtained from this review may help minimally invasive gynecologists seek out appropriate partnerships in lowresource settings for mutually beneficial training experiences for trainees from both countries.

Data collection and research also need be prioritized in order to make minimally invasive techniques more accessible and safe for patients in LMICs. Anticipatory planning can help improve the cost-effectiveness of surgical care [31]. Such planning is only done by understanding the magnitude of problems within a particular infrastructure through data collection systems. As the WHO and others aim for a global surgical database for quality and safety, it will be important for the same measures be applied to laparoscopic and hysteroscopic operations. Data collection and research is imperative to the quality improvement process while developing nations advance their expertise with these techniques.

\section{References}

1. Verguet S, Alkire BC, Bickler SW, Bickler SW, Lauer JA, et al. (2015) Timing and cost of scaling up surgical services in low-income and middle-income countries from 2012 to 2030: a modelling study. The Lancet Global Health 3(S2): S28-S37.

2. Jamison DT, Breman JG, Measham AR (2006) Surgery, in Disease Control Priorities in Developing Countries. Oxford University Press, Washington, USA.
3. Haynes AB, Wesier TG, Berry WR, Lipsitz SR, Breizat AS, et al. (2009) A surgical safety checklist to reduce morbidity and mortality in a global population. New England Journal of Medicine 360(5): 491-499.

4. Okrainec A, Smith L, Azzie G (2009) Surgical simulation in Africa: the feasibility and impact of a 3-day fundamentals of laparoscopic surgery course. Surg Endosc 23(11): 2493-2498.

5. Chao TE, Mandigo M, Opoku-Aane J, Maine R (2015) Systematic review of laparoscopic surgery in low- and middle-income countries: benefits, challenges, and strategies. Surg Endosc 30(1): 1-10.

6. Efetie ER, Abubakar JS, Habeeb SA (2009) Audit of Gynaecological Laparoscopies in National Hospital Abuja, Nigeria. Nigerian Journal of Clinical Practice 12(2): 149-152.

7. Yakasai IA, Abdullahi J, Omole-Ohonsi A, Ibrahim SA (2012) Gynaecologic Laparoscopy at Aminu Kano Teaching Hospital, Kano, Nigeria: A 5-Year Review. British Journal of Science 5(1): 11-17.

8. Mboudou E, Frederick LI, Pascal F, Sama JD, Mbatsogo BAE, et al. (2014) Gynaecological laparoscopic surgery: eight years experience in the Yaoundé Gynaeco-Obstetric and Paediatric Hospital, Cameroon. Trop Doct 44(2): 71-76.

9. Badejoko OO, Adeyemi AB, Ijarotimi AO, Awowole IO, Ogunniyi SO (2013) Operative Gynecologic Laparoscopy in Ile-Ife, Nigeria: A Preliminary Experience. Journal of Gynecologic Surgery 29(4): 186189.

10. Djehdian LM, Araujo MP, Takano CC, Del-Roy CA, Sartori MG, et al. (2014) Transobturator Sling Compared with Single Incision Mini Sling for the Treatment of Stress Urinary Incontinence. Obst and Gynec 123(3): 553-561.

11. Sardi J, Vidaurreta J, Bermúdez A, di Paola G (1999) Laparoscopically Assisted Schauta Operation: Learning Experience at the Gynecologic Oncology Unit, Buenos Aires University Hospital. Gynecologic Oncology 75(3): 361-365.

12. Vidaurreta J, Bermúdez A, di Paola G, Sardi J (1999) Laparoscopic Staging in Locally Advanced Cervical Carcinoma: A New Possible Philosophy? Gynecologic Oncology 75(3): 366-371.

13. Meara JG, Leather AJM, Hagander L, Alkire BC, Alonso N, et al. (2015) Global Surgery 2030: evidence and solutions for achieving health, welfare, and economic development. Lancet 386(9993): 569-624.

14. Ozgediz D, Dunbar P, Mock C, Cherion M, Rogers SO, et al. (2009) Bridging the gap between public health and surgery: access to surgical care in low- and middle-income countries. Bull Am Coll Surg 94(5): 1420.

15. Luboga S, Macfarlane SB, von Schreeb J, Kruk ME, Cherian MN, et al (2009) Increasing access to surgical services in sub-saharan Africa: priorities for national and international agencies recommended by the Bellagio Essential Surgery Group. PLoS Med 6(12): e1000200.

16. Shrestha J, Saha R (2012) Comparison of Laparoscopy and Laparotomy in the Surgical Management of Ectopic Pregnancy. J Coll Physicians Surg Pak 22(12): 760-764.

17. Jahan S, Das TR, Mahmud N, Mondol SK, Habib SH, et al. (2011) A comparative study among laparoscopically assisted vaginal hysterectomy, vaginal hysterectomy and abdominal hysterectomy: experience in a tertiary care hospital in Bangladesh. J Obstet Gynaecol 31(3): 254-257.

18. Pareja R, Nick AM, Schmeler KM, Frumovitz M, Soliman PT, et al (2012) Quality of laparoscopic radical hysterectomy in developing countries: A comparison of surgical and oncologic outcomes between a comprehensive cancer center in the United States and a cancer center in Colombia. Gynecologic Oncology 125(2): 326-329. 
19. Choy I, Kitto S, Adu-Aryee N, Okrainec A (2013) Barriers to the uptake of laparoscopic surgery in a lower-middle-income country. Surg Endosc 27(11): 4009-4015.

20. Shrime MG, Sleemi A, Ravilla TD (2015) Charitable Platforms in Global Surgery: A systematic review of their effectiveness, cost -effectiveness, sustainability, and Role Training. World J Surg 39(1): 10-20.

21. Johnson WD (2013) Surgery as a Global Health Issue. Surg Neurol Int 4: 47.

22. Puntambekar SP, Agrawal GA, Joshi SN, Rayate NV, Saravana DNB, et al. (2014) Laparoscopic Gynaeoncological Procedures: Lessons Learnt After a Single Institution Audit of Complications and Their Management in 567 Consecutive Patients. The Journal of Obstetrics and Gynecology of India 64(1): 36-40.

23. Gomes MTV, Neme RM, Vanni DG, Brudniewski HF (2013) Robotic Hysterectomy: 30 Month Follow-Up Data in Albert Einstein Hospital in Sao Paulo, Brazil. JMIG 20(6): S171.

24. Brummer THI, Seppala TT, Harkki PSM (2008) National learning curve for laparoscopic hysterectomy and trends in hysterectomy in Finland 2000-2005. Human Reproduction 23(4): 840-845.

25. Tian YF, Lin YA, Lu CL, Chia CC, Huang KF, et al. (2007) Major complications of operative gynecologic laparoscopy in Southern Taiwan: A follow-up study. The Journal of Minimally Invasive Gynecology 14(3): 284-292.

26. Margrina JF (2002) Complications of laparoscopic Surgery. Clin Obstet Gynecol 45(2): 469-480.

27. Parkar RB, Thagana NG, Barazaz R, Otieno D (2003) Experience with Laparoscopic Surgery at the Aga Khan Hospital, Nairobi. East African Medical Journal 80(1): 44-50.

28. Raiga J, Kaisa JM, Bruhat MA (1999) Laparoscopic Surgery in Cameroon. International Journal of Gynecology and Obstetrics 65: 65-99.

29. Whitted RW, Pietro PA, Martin G, Latchaw G, Medina C (2003) A retrospective study evaluated the impact of formal laparoscopic training on patient outcomes in a residency program. J Am Assoc Gynecol Laparosc 10(4): 484-448.

30. Minig L, Velazco A, Lamm M, Velez JI, Venturini N, Testa CR (2010) Evaluation of laparoscopic management of gynecologic emergencies by residents. Int J Gynecol Obstet 111(1): 62-67.

31. Weiser TG, Makary MA, Haynes AB, Dziekan G, Berry WR, et al. (2009) Standardised metrics for global surgical surveillance. Lancet 374: 1113-1117.

\section{Supplimentary References}

1. Habibaj J, Kosova H, Bilali S, Bilali V, Qama D (2012) Comparison between transvaginal sonography after diagnostic hysteroscopy and laparoscopic chromopertubation for the assessment of tubal patency in infertile women. J Clin Ultrasound 40(2): 68-73.

2. Sardi J, Vidaurreta J, Bermúdez A, di Paola G (1999) Laparoscopically Assisted Schauta Operation: Learning Experience at the Gynecologic Oncology Unit, Buenos Aires University Hospital. Gynecologic Oncology 75(3): 361-365

3. Vidaurreta J, Bermúdez A, di Paola G, Sardi J (1999) Laparoscopic Staging in Locally Advanced Cervical Carcinoma: A New Possible Philosophy? Gynecologic Oncology 75(3): 366-371.

4. Buquesta RA, Amatob AR, Huang GB, Singlaa J, Ortiza OC (1999) Is preoperative selection of patients with cystic adnexal masses essential for laparoscopic treatment? The Journal of the American Association of Gynecologic Laparoscopists 6(4): 477-481.

5. Kreiker GL, Bertoldi A, Larcher JS, Orrico GR, Chapron C (2004) Prospective Evaluation of the Learning Curve of Laparoscopic-Assisted
Vaginal Hysterectomy in a University Hospital. J Am Assoc Gynecol Laparosc 11(2): 229-235.

6. Jahan S, Das TR, Mahmud N, Mondol SK, Habib SH, et al. (2011) A comparative study among laparoscopically assisted vaginal hysterectomy, vaginal hysterectomy and abdominal hysterectomy: experience in a tertiary care hospital in Bangladesh. J Obstet Gynaecol 31(3): 254-257.

7. Jahan S, Jahan A, Joarder M, Habib SH, Sharmin F, et al. (2015) Laparoscopic hysterectomy in large uteri: Experience from a tertiary care hospital in Bangladesh. Asian J Endosc Surg.

8. Djehdian LM, Araujo MP, Takano CC, Del-Roy CA, Sartori MG, et al. (2014) Transobturator Sling Compared with Single Incision Mini Sling for the Treatment of Stress Urinary Incontinence. Obst and Gynec 123(3): 553-561.

9. Gomes MTV, Neme RM, Vanni DG, Brudniewski HF (2013) Robotic Hysterectomy: 30 Month Follow-Up Data in Albert Einstein Hospital in Sao Paulo, Brazil. JMIG 20(6): S171.

10. Mboudou E, Frederick LI, Pascal F, Sama JD, Mbatsogo BAE, et al. (2014) Gynaecological laparoscopic surgery: eight years experience in the Yaoundé Gynaeco-Obstetric and Paediatric Hospital, Cameroon. Trop Doct 44(2): 71-76.

11. Raiga J, Kasia JM, Bruhat MA (1999) Brief Communication: Laparoscopic Surgery in the Cameroon. International Journal of Gynecology and Obstetrics 65: 65-66.

12. Yi C, Li L, Wan X, Liu X (2014) Recurrence of uterine tissue residues after laparoscopic hysterectomy or myomectomy. Pak J Med Sci 30(5): 1134-1136.

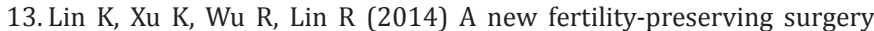
for interstitial pregnancy involving hysteroscopic removal under laparoscopic guidance. Int J Gynaecol Obstet 124(3): 256-264.

14. Wang T, Huang S, Geng G (2014) Comparison of the duration of neuromuscular blockade following a single bolus dose of rocuronium during laparoscopic gynaecological surgery vs conventional open surgery. Anaesthesia 69(8): 854-859.

15. Pareja R, Nick AM, Schmeler KM, Frumovitz M, Soliman PT, et al (2012) Quality of laparoscopic radical hysterectomy in developing countries: A comparison of surgical and oncologic outcomes between a comprehensive cancer center in the United States and a cancer center in Colombia. Gynecol Oncol 125: 326-329.

16. Gonzalez JEB, Pena RT, Faife B (2011) Validation of the laparoscopic hysterectomy through a single port as a new technique in Cuba. Revista Cubana de Cirugia 50(4): 525-533.

17. Krentel H, Ruiz MA (2012) Laparoscopy in the public health system in Ecuador: an evaluation of the status quo and the education in minimally invasive surgery. Gynecological Surgery 9(3): 283-287.

18. Siam S (2013) Gynecologic laparoscopy and reproductive failure: Review of 4103 infertile Egyptian Women. MEFS 19: 102- 106.

19. El Saman AM (2009) Combined retropubic balloon vaginoplasty and laparoscopic canalization. Am J Obstet Gynecol 201(3): 333.

20. Siam S, Soliman BS (2014) Combined laparoscopy and hysteroscopy for the detection of female genital system anomalies results of 3,811 infertile women. J Reprod Med 59(11-12): 542-546.

21. Abuelghar W, Bayoumy H, Ellaithy M, Khalil MS (2014) Women with clomiphene citrate resistant polycystic ovarian disease: predictors of spontaneous ovulation after laparoscopic ovarian drilling. Eur J Obstet Gynecol Reprod Biol 175: 178-185.

22. Mohamed ML, El Behery MM, Mansour SA (2013) Comparative study between VEGF-A and CA-125 in diagnosis and follow-up of advanced 
endometriosis after conservative laparoscopic surgery. Arch Gynecol Obstet 287(1): 77-82.

23. Andreatta P, Perosky J, Klotz J (2014) Pilot Study Outcomes from a resource-limited setting for a low-cost training program for laparoscopic surgical skills. International Journal of Gynecology and Obstetrics 125: 186-188.

24. Kim J, Patzkowsky K, Xu X, Dalton V, Advincula A (2009) University of Michigan 0475: Sustaining a gynecologic operative laparoscopic training program in Ghana. International Journal of Gynecology \& Obstetrics 107(S2): S93-S396.

25. Maxis CP, Tang NZ, Lian X, D'Hait S, Millien C (2014) Bringing Laparoscopy to Haiti, a Pilot Program. Journal of Minimally Invasive Gynecology 21(6): S45-S90.

26. Szendei GA (2009) Endometriosis in Hungary. Gynecological Endocrinology 25(11): 694-700.

27. Török P, Major T (2012) Accuracy of Assessment of Tubal Patency With Selective Pertubation at Office Hysteroscopy Compared With Laparoscopy in Infertile Women. JMIG 19(5): 627-630.

28. Drozgyik I, Vizer M, Szabó I (2007) Significance of laparoscopy in the management of chronic pelvic pain. European Journal of Obstetrics \& Gynecology and Reproductive Biology 133(2): 223-226.

29. Puntambekar SP, Agarwal GA, Puntambekar SS, Sathe RM, Patil AM (2009) Stretching the Limits of Laparoscopy in Gynecological Oncology: Technical Feasibility of doing a Laparoscopic Total Pelvic Exenteration for Palliation in advanced Cervical Cancer. Int J Biomed Sci 5(1): 17-22.

30. Puntambekar SP, Kathya N, Reddy MC, Puntambekar SS, Agarwal G, et al. (2014) Indian Experience of Robotics in Gynecology J Minim Access Surg 10(2): 80-83.

31. Puntambekar SP, Patil AM, Rayate NV, Puntambekar SS, Sathe RM, et al. (2010) A Novel Technique of Uterine Manipulation in Laparoscopic Pelvic Oncosurgical Procedures: "The Uterine Hitch Technique". Minimally Invasive Surgery Article ID 836027.

32. Hemal AK, Surendra BK, Wadhwa P (2008) Robotic Reconstruction for Recurrent Supratriagonal Vesicovaginal Fistulas. The journal of urology 180(3): 981-985.

33. Puri S, Jain D, Puri S, Kaushal S, Deol KS (2015) Laparohysteroscopy in female infertility: A diagnostic cum therapeutic tool in Indian setting. Int J Appl Basic Med Res 5(1): 46-48.

34. Shrivastava D, Sindhu B, Mukherjee S (2010) Role of Laparoscopic Ovarian Drilling as a First Line Management in Infertility with Polycystic Ovarian Disease. South Asian Federation of Obstetrics and Gynecology 2(2): 123-126.

35. Wadia BJ, Joshi NU, D'souza D (2000) Laparoscopic Sterilization in Rural India, Indira Gandhi Medical College, India. Intl J Gyn Obs 2: B100.

36. Fard S, Gharabaghi MP, Montazeri F, Mashrabi O (2012) Hysteroscopy as a minimally invasive surgery, a good substitute for invasive gynecological procedures. Iran J Reprod Med 10(4): 377-382.

37. Alborzi S, Asadi N, Zolghadri J, Alborzi S, Alborzi M (2009) Laparoscopic metroplasty in bicornuate and didelphic uteri. Fertil Steril 92(1): 352355.

38. Alborzi S, Momtahan M, Parsanezhad ME, Dehbashi S, Zolghadri J, et al. (2004) A prospective, randomized study comparing laparoscopic ovarian cystectomy versus fenestration and coagulation in patients with endometriomas. Fertil Steril 82(6): 1633-1637.

39. Alborzi S, Ghannadan E, Alborzi S, Alborzi M (2009) A comparison of combined laparoscopic uterine artery ligation and myomectomy versus laparoscopic myomectomy in treatment of symptomatic myoma. Fertil Steril 92(2): 742-747.
40. Parkar B (2009) Laparoscopic Management of Uterine Perforation: Report of Three cases. East African Medical Journal 86(3): 143-145.

41. Parkar RB (2004) Hysteroscopic Surgery at The Aga Khan Hospital, Nairobi. East African Medical Journal 81(7).

42. Parkar RB, Thagana NG, Barazaz R, Otieno D (2003) Experience with Laparoscopic Surgery at the Aga Khan Hospital, Nairobi. East African Medical Journal 80(1).

43. Sikolia Z, Wanyonyi A, Sequeira EA, Mukono SG (2011) Correlation between laparoscopic and histopathologic diagnosis of endometriosis. International Journal of Gynecology and Obstetrics 115: 272-275.

44. Abu-Musa A, Nassar A, Usta I, Khalil A, Hussein M (2001) Laparoscopic unwinding and cystectomy of twisted dermoid cyst during second trimester of pregnancy. J Am Assoc Gynecol Laparosc 8(3): 456-460.

45. Lim YH, Ng SP, Ng PHO, Tan AE, Jamil MA (2007) Laparoscopic salpingectomy in tubal pregnancy: Prospective randomized trial using endoloop versus electrocautery. J Obstet Gynaecol Res 33(6): 855-862.

46. Díaz D, Barrón J, Rojas G, Kably A (1998) Laparoscopia ginecológicaen el Hospital ABC. Análisis de 882 casos. Ginecol Obstet Mex 66: 395-399.

47. Saha R, Karki C (2013) Laparoscopic Management of Benign Ovarian Masses. J Nepal Med Assoc 52(192): 608-611.

48. Saha R, Shrestha NS, Thapa M, Shrestha J, Bajracharya J, et al. (2013) Experiences of Gynecological Laparoscopic Surgeries in a Teaching Hospital. J Negal Health Res Counc 11(23): 49-52.

49. Shrestha J, Saha R (2012) J Coll Physicians Surg Pak 22(12): 760-764.

50. Efetie ER, Abubakar JS, Habeeb SA (2009) Audit of Gynaecological Laparoscopies in National Hospital Abuja, Nigeria. Nigerian Journal of Clinical Practice 12(2): 149-152.

51. Ikechebelu JI (2013) Experience with diagnostic laparoscopy for gynecological indications. Nigerian Journal of Clinical Practice 16(2): 155-158.

52. Badejoko 00, Adeyemi AB, Kuti O, Ijarotimi AO, Loto OM, et al. (2013) Operative Gynecologic Laparoscopy in Ile-Ife, Nigeria: Preliminary Experience. Journal of Gynecologic Surgery 29(4): 186-189.

53. Badejoko O0, Ibraheem OA, Imaralu JO (2013) Laparoscopic Salpingectomy for Heterotopic Pregnancy, A case report form Ile-Ife, Nigeria. Journal of Gynecologic Surgery 29(2): 96-98.

54. Okunlola OJ, Adebayo AA, Odukogbe IO, Morhason-Bello KM, Owonikoko (2005) Assessment of tubal factor contribution to female infertility in a low resource setting (southwest Nigeria): Hysterosalpingography vs laparoscopy. Journal of Obstetrics \&Gynaecology 25(8): 803-804.

55. Arowojolu O, Ilesanmi AO (1998) Clinical and laparoscopy diagnosis of acute pelvic inflammatory disease in Nigeria Journal of Obstetrics \& Gynaecology 18(3): 276-277.

56. Rehman R, Rao SI, Siddiq S (2011) Frequency of Various Laparoscopic Diagnostic Findings in Subfertile Women. JSOGP 1(4).

57. Rizvi RM, Akhtar M, Zuberi NF (2013) A Review of Comparison of Complications of Vaginal Hysterectomy with and without Concomitant Surgery for SUI: A 5 Years' Experience at a Tertiary Care Hospital of Pakistan. Obstetrics and Gynecology International Article ID 540646.

58. Rizvi US, Iftikhar T, Bano N (2011) Laparoscopic Outcome of Infertility. JSOGP 1(2).

59. Mushtaq R, Mushtaq M, Iqbal S (2012) Outcome of Laparoscopies for Subfertility in Military and Combine Military Hospitals Rawalpindi. JSOGP 2(1): 3-36.

60. Parveen S, Khanam M (2010) Role of Combined Diagnostic Laparoscopy and Simultaneous Diagnostic Hysteroscopy for Evaluation of Female Subfertilty Factors. Journal of Surgery Pakistan 15(1): 1-4. 
61. Parveen S, Jehan M, Valliani RR (2013) Open Versus Closed Entry Techniques of Laparoscopy in Gynecological Practice. Journal of Surgery Pakistan 18(4): 160-162.

62. Memon MR, Memon SR, Mirani SH, Memon NY (2014) Role of Laparoscopy in Acute Gynecologic Conditions. Rawal Medical Journal 39(1): 48-51.

63. Memon MR, Memon SR, Shaikh AA, Memon NY (2013) Role of Laparoscopy in Chronic Pelvic Pain. Rawal Medical Journal 38(4).

64. Iftikhar R (2008) Outcome of Laparoscopy in Chronic Pelvic Pain. Journal of Surgery Pakistan 13(4): 155-158.

65. Molinas CR, Campo R (2010) Defining a structured training program for acquiring basic and advanced laparoscopic psychomotor skills in a simulator. Gynecological Surgery 7(4): 427-435.

66. Ferreira R, Farina C, Gamarra J , Domínguez R, Martínez N, et al. (2012) Emergency Laparoscopy Surgery, Our Results. Rev Cir Parag 36(1): 2124.

67. Rechkemmer AF, Allemant J (2008) Treatment of cervical pregnancy with laparoscopy-assisted uterine artery blockade followed by hysteroscopicendo cervical resection: report of two cases. 90: S169.

68. kemmer A (2009) Creation of neovagina using laparoscopically assisted mobilized peritoneum: Report of two cases. International Journal of Gynecology \& Obstetrics 107(S2): S413-S729.

69. Dragusin R, Tudorache S, Surline V, Lichiardopol C, Iliescu DG (2014) Importance of Laparosocpic Assessment of the Uterine Adnexa in a Mayer-Rokitansky-Kuster-Hauser Syndrome Type II Case. Current Health Sciences Journal 40(2): 144-147.

70. Dhont N, Lucther S, Ombelet W, Vyankandondera J, Gasarabwe A, et al. (2010) Gender Differences and factors associated with treatmentseeking behaviour for infertility in Rwanda. Human Reproduction 25(8): 2024-2030.

71. Popović J, Sulović V, Vucetić D (2005) Laparoscopy treatment of adnexal sterility. Clin Exp Obstet Gynecol 32(1): 31-34.

72. Prorocic M, Tasic L, Vasiljevic M, Jurisic A, Smiljkovic OD, et al. (2013) Simultaneous dermoid cyst and endometriosis in the same ovary: a case report. Clin Exp Obstet Gynecol 40(3): 457-459.

73. Butt JL, Jeffery ST, Van de Spuy ZM (2012) An audit of indications and complications associated with elective hysterectomy at a public service hospital in South Africa. International Journal of Gynecology and Obstetrics 116(2): 112-116.

74. Gunawardena GHKK, Priyananda KGW, Jayalath GKC, Disanayake DMP (2009) A case series on current management options of tubal ectopic pregnancy in a tertiary care unit. Sri Lanka Journal of Obstetrics and Gynaecology 31: 16-19.

75. Mirghani O, Babiker MY (1999) Experience with gynaecological laparoscopies in Wad Medani Hospital, Sudan. East Afr Med J 76(7): 390-395.

76. Omer M (2009) Establishment of a gynecological laparoscopy unit in Omdurman Maternity Hospital, Sudan challenges and outcome. Int J Gynecol Obstet 107: 298.

77. Kassam SH, Kassam GB (2002) Georgia Physicians in Central Asia. Obstetrics \& Gynecology in Tajikistan: Introduction of Laparoscopy. J Med Assoc Ga 91(3): 29-30.

78. Manchana T, Sirisabya N, Vasuratna A (2014) Feasibility and Safety of Robotic Surgery for Gynecologic Cancers. Asian Pacific Journal of Cancer Prevention 15: 5359-5364.

79. Wongpia I, Thinkhamrop J1, Seejorn K1, Buppasiri P, Luanratanakorn $\mathrm{S}$, et al. (2014) Incidence of and risk factors febrile morbidity after laparoscopic-assisted vaginal hysterectomy. Intl J Women's Health 4(6): 385-388.
80. Nutthachote P, Sirayapiwat P, Wisawasukmongchol W, Charuluxananan S (2014) A randomized, double-blind, placebo-controlled trial of oral pregabalin for relief of shoulder pain after laparoscopic gynecologic surgery. J Minim Invasive Gynecol 21(4): 669-673.

81. Teerapong S, Rungaramsin P, Tanprasertkul C, Bhamarapravatana K, Suwannarurk K (2012) Major complication of gynaecological laparoscopy in Police General Hospital: a 4-year experience. J Med Assoc Thai 95(11): 1378-1383.

82. Khampitak K, Werawatakul Y, Supokhen A, Seejorn K (2012) A modified LAVH to reduce urinary tract injuries: 102 consecutive case-series at Srinagarind Hospital, KhonKaen University. J Med Assoc Thai 95(3): 299-306.

83. Tanaprasertkul C, Manusook S, Somprasit C (2014) Antimullerian Hormone Changes after laparoscopic ovarian cystectomy for endometrioma compared with non-ovarian conditions. Minim Invasive Surg 2014: 654856

84. Nazik H, Gul S, Narin R, et al. (2014) Complications of gynecological laparoscopy: experience of a single center Clin Exp Obstet Gynecol 41(1): $45-47$.

85. Capar M, Balci O, Acar A, Karatyli R (2008) Transvaginal Burch operation for stress urinary incontinence: 5-year results. BJOG 115(3): 1709-1712.

86. Göçmen A, Şanlıkan F, Uçar MG (2010) Turkey's experience of roboticassisted laparoscopic hysterectomy: a series of 25 consecutive cases. Archives of Gynecology and Obstetrics 282(2): 163-171.

87. Baydo SV, Vinnytska AB, Zhygulin AV, Golub DA, Pryndyuk SI, et al. (2014) Our experience of radical totally laparoscopic operation in oncology. Eur J Surg Oncol 40(11): S150.

88. Narzullaev KB, Azimov SA (2002) Simultaneous Operations in Gynecology and Surgery. J Minim Invasive Gynecol 9: 40.

89. Kalegyn AV, Mayram H, Sadykova (2001) Marsupialization of the Cyst as a Step in Laparoscopic Management of Ovarian Cysts 8(4): 568-572.

90. Sotelo R, Astigueta JC, Carmona O, De Andrade R, Sanchez-Salas R (2009) Laparoendoscopic single-site surgery (less): initial experience. Actas Urológicas Españolas 33(2): 172-181.

91. Sotelo R, Mirandolin BM, Garcia-Segui A, Dubois R, Spaliviero M, et al. (2005) Laparoscopic Repair of vesicovaginal fistula. The Journal of Urology 173: 1615-1618.

92. Nguyen BN, Nguyen NP (2002) Laparoscopic Surgery of Ovarian Endometrioma. J Minim Invasive Gynecol 9: 40.

93. Alejandro AB, Mojarra-Estrada JM, Carvajal A, Figueroa-Damián R (2009) Coccidioidomicosis peritoneal como causa de infertilidad: Reporte de un caso. Perinatologia y Reproduccion Humana 23(3): 150155.

94. Clin Exp Obstet Gynecol (2005) 32(1): 31-4.

95.http://kfh.rw/2012/04/20/rwanda-gynecologists-gainedlaparoscopic-surgery-skills-at-rbcking-faisal-hospital-kigali/

96. Romero MRP (2014) Video by laparoscopic management of a giant ovarian cyst, case report. Rev med Hondur 82(2).

97. Parkar RB (2011) Laparoscopic Trachelectomy for Cervical Stump 'Carcinoma in situ'. J Gynecol Endosc Surg 2(1): 58-60.

98. Shailesh P, Geetanjali A, Saurabh JN, Neeraj RV, Saravana DNB, et al. (2014) Laparoscopic Gynaeoncological Procedures: Lessons Learnt After a Single Institution Audit of Complications and Their Management in 567 Consecutive Patients. The Journal of Obstetrics and Gynecology of India 64(1): 36-40.

99. Jayarathna J, Ranaraja S, Sumathipala DS (2015) Analyzing the necessity of prophylactic antibiotic usage in laparoscopy for uncomplicated 
gynecologic conditions in Sri Lanka. J Obstet Gynaecol Res 41(4): 596600.

100. Puntambekar SP, Wagh GN, Puntambekar SS, Sathe RM (2008) A Novel Technique of Total Laparoscopic Hysterectomy for Routine Use: Evaluation of 140 Cases. Intl J Biomedical Sciences 4(1): 38-43.

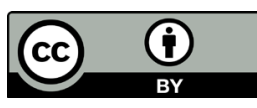

This work is licensed under Creative Commons Attribution 4.0 Licens

DOI: $10.19080 / J G W H .2017 .04 .555643$

\section{Your next submission with Juniper Publishers} will reach you the below assets

- Quality Editorial service

- Swift Peer Review

- Reprints availability

- E-prints Service

- Manuscript Podcast for convenient understanding

- Global attainment for your research

- Manuscript accessibility in different formats ( Pdf, E-pub, Full Text, Audio)

- Unceasing customer service

Track the below URL for one-step submission https://juniperpublishers.com/online-submission.php 